Were there nonhumans in Bagua? | 62

THOMAS NIEDERBERGER ${ }^{1}$

\title{
Were there Nonhumans in Bagua? \\ The Gobierno Territorial \\ Autónomode la Nación Wampis \\ and the Emergence of Vertical \\ Territoriality in the Northern \\ Peruvian Amazon ${ }^{2}$
}

The territory of the Wampis nation integrates diverse spaces whose inhabitants are all related to each other. Entsa, the aquatic space, is where the tsunki shuar live. Nunka, the earth space, is inhabited by [...] human beings, the animals and their owners, iwanch and tijae, the plants and their mothers, particularly nunkui, who lives inside the earth, as well as the rivers, hills and waterfalls. Nayaim, the air, or heaven space, which is not separated from earth, is inhabited by Etsa (sun), our guide, yaa (stars) and Nantu (moon) as well as ujumak and many more beings that give us their power, and this is where our ancestors dwell. All these spaces are alive and depend on each other. Our nation and its people are part of this territory.

(Statute of the Wampis Nation, Article 21: Cultural definition of the Wampis territory (author's own translation))

As proclaimed in a general assembly of the Wampis people in November 2015, the Gobierno Territorial Autónomo de la Nación Wampis (GTANW) seeks selfdetermination over an 'integral territory' of 1.3 million hectares in the northern

\footnotetext{
${ }^{1}$ Thomas Niederberger is a PhD student at the Institute of Social Anthropology, University of Bern. Funding for this project was provided through a mobility grant of the SNSF.

${ }^{2}$ This article was originally published in http://www.alternautas.net/blog/2020/2/12/werethere-nonhumans-in-bagua-the-gobierno-territorial-autnomo-de-la-nacin-wampis-and-theemergence-of-vertical-territoriality-in-the-northern-peruvian-amazon
} 
Peruvian Amazon. In the GTANW's statute, this territory is defined as being alive and holds a variety of interrelated human and nonhuman beings. By invoking tsunki, nunkui, ujumak and the rest, the statute departs from the use of purely legal and eco-technocratic terminology in past public statements by Wampis political organisations. The first indications of this shift coincide with the uprising at Bagua, to which the title of this article refers.

Responding to a neoliberal attack under then president of Peru, Alan García, in 2009 around 5,000 indigenous warriors - among them 1,200 Wampis - clashed with police, resulting in the 'massacre of Bagua' (or 'Baguazo') on 5 June, with an official death toll of thirty-four (ten civilians and twenty-four police) and hundreds wounded. Marisol de la Cadena notes the reaction of García to the protesters at Bagua in order to illustrate the scandal caused by the appearance of nonhuman actors on the political stage. Responding to the indigenous who 'claimed the rivers [...] as their brothers' ${ }^{3}$ in arguing against the presence of extractive companies, García famously uttered: 'Who are 400,000 natives to tell 28 million Peruvians that you have no right to come here? This is a grave error, and whoever thinks this way wants to lead us to irrationality and a retrograde primitivism' (cited in De la Cadena 2015). The contempt expressed by this former Peruvian president may explain why indigenous people have shied away from mentioning relations with nonhumans in the past, even when in the presence of sympathetic audiences and anthropologists. In this context, the incidents at Bagua amounted to an 'ontological conflict', challenging the hegemonic assumption of an all-encompassing modernity with its underlying nature-culture divide (Blaser 2013).

In this article, I trace how Wampis have started openly and visibly to mobilise nonhuman actors in eco-political struggles. This opens a vertical dimension to the

\footnotetext{
${ }^{3}$ De la Cadena here cites an interview with a face-painted Awajún man called Lenny, from the video 'Los Sucesos de Bagua' (www.servindi.org/producciones/videos/13083, minute 4:30) [accessed 19.09.2018]. Rather than being a reference to a specific water being such as tsunki, he seems to make a general comment on the importance of rivers and water. A similar statement is made by Awajún leader Santiago Manuin: 'the forest, the air, the hills are our brothers [...] our Bible is written there' (author's own translation, cited in Espinosa 2009).
} 
defence of territory - the extension of relationships into the underground and atmosphere - which comes to the fore in parallel with the advancing recognition of nonhumans as right-holders (Surrallés 2017).

Here, I present results from engaged anthropology as a member of the equipo técnico (technical team) of the GTANW's intermediate governance level, the Gobierno de Cuenca Kanus (the former federation of Rio Santiago, FECOHRSA) - a role carried out over a two-year period (2016-2018). In April 2019, I returned to Peru and discussed the main hypothesis of this article with several of the main leaders and intellectuals in the GTANW - the pamuk (president) Wrays Pérez, Juan Nuningo, Julio Hinojosa and Kefren Graña - as well as with my research partner Geronimo Petsain.

To sum up these discussions, Wampis leaders insist that nonhumans have always been central for territorial defence, even though this was not acknowledged publicly or in written form. Instead, they used the conservationist language of "protecting nature, forest and climate" as placeholder for the care of relationships with nonhumans. The change to an explicit invocation came with the realisation that to support their claim for the integral territory, a legal fundament based on ancestral usage and practices was needed. Going beyond the horizontal dimension of territoriality, the underground and the wider atmosphere became increasingly important in the context of oil and mining projects as well as for conservationist and carbon offset schemes. In this manner, indigenous leaders' mediation and translations between ontological features and global eco-political discourses prepared the ground for an emergent eco-autonomy that includes what I call 'vertical territoriality'.

\section{Introducing the 'integral territory' and autonomous government}

The Wampis territory is situated in the Andean foothills, South of the Ecuadorean border, along the two rivers Santiago and Morona (Kanus and Kankaim in Wampis); it has a population of around 15,000 individuals. As part of the Jivaro (or Chicham) group, they have been known for a strong warrior ethics ever since their 
successful expulsion of the Spanish conquistadores from their lands in 1599. Only with the militarisation in the context of border wars with Ecuador in the 1940s did the Peruvian state take control of the area (Campion 2018). From the 1950s onwards, Wampis allowed missionaries to open schools, settling in riverside "native communities" and during the 1970s-1990s obtained legal land titles for individual communities.

The genesis of the Wampis nation's autonomous territorial government (GTANW) and the vision of forming an integral territory can be traced to two meetings of the regional federation CORPI San Lorenzo (Coordinadora Regional de Pueblos Indigenas) in 1995 and 1996. There, representatives of various peoples of the Loreto region drew draft maps of their integral territories and resolved to seek land titles 'per people' instead of the existing fragmented titles that were designated 'per community' (Noningo 2018; Chirif, García Hierro and Chase-Smith 1991).

After a long time gap, from 2007 onwards CORPI assisted in preparing the paper groundwork: defining borders, solving related disputes and commissioning legal and anthropological expertise (Garra and Riol Gala 2014). In the accompanying debates, it was resolved that an integral territory also called for an institution of governance - an autonomous territorial government - for its representation towards the state; this was a task that the previous federations of communities were no longer able to fulfil due to their fragmentation.

In November 2015, the Wampis were the first people in Peru to officially proclaim their autonomous government and integral territory, at a general assembly in the village of Soledad with 300 representatives of 85 communities. They adopted the statute of the Wampis nation, elected a pamuk and approved a first ordinance. ${ }^{4}$ Carefully drafted along the lines of the UN Declaration on the Rights of

4 'Pueblo Wampis conforma primer gobierno autónomo indígena del Perú, Servindi, 30 November 2015, https://www.servindi.org/actualidad/144577 [accessed 19.09.2018]. The Awajún, Achuar, Kandoshi, Cocama-Cocamilla, Kichwa, Chapra, Shawi and Shiwilu are advancing in the same direction. The total self-demarcated territory of these peoples covers 9.3 million hectares (about the size of Portugal) in the northern Peruvian Amazon (Surrallés and Tuesta 2017). 
Indigenous Peoples (UNDRIP) and Convention 169 of the International Labour Organization (ILO), the GTANW has received considerable international attention. Despite this, the Peruvian government has so far not taken an official position regarding the Wampis' exercise of self-determination.

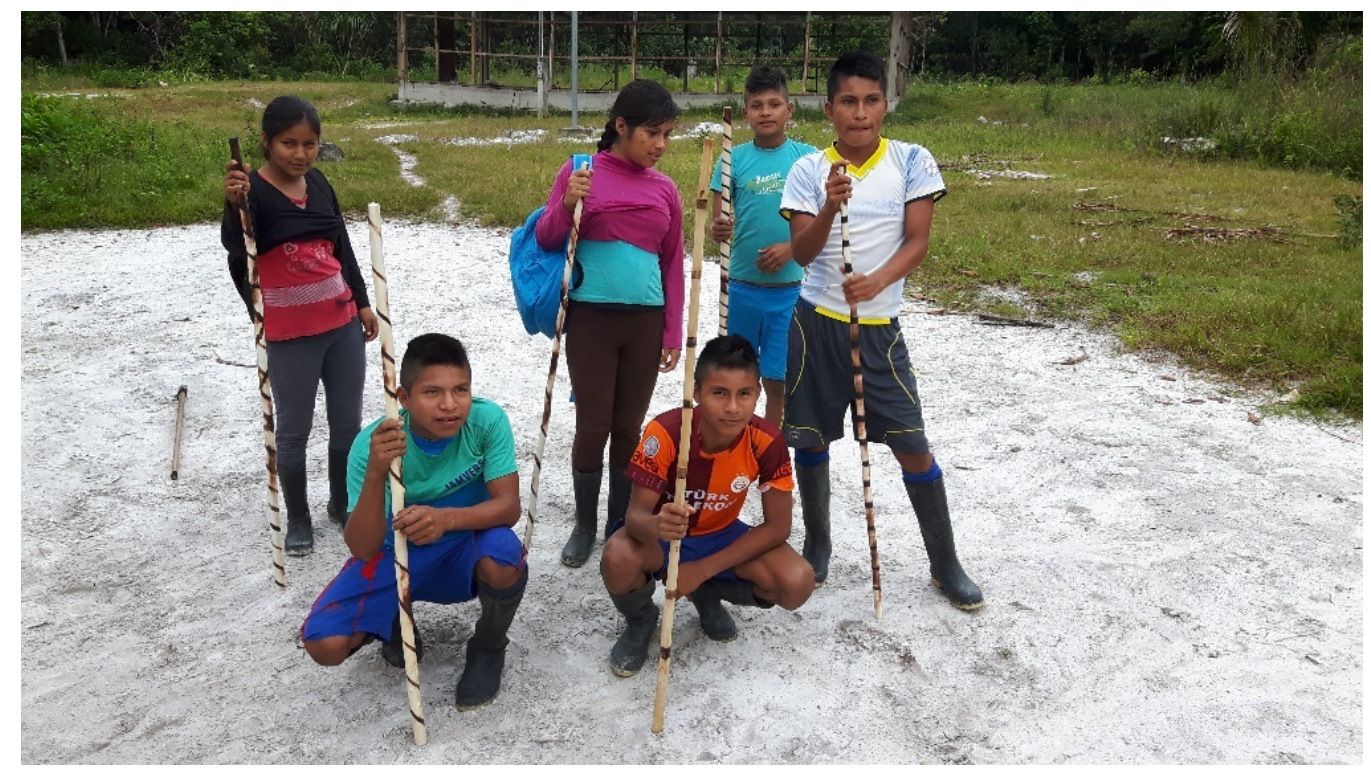

A group of Wampis youth ready for a three-day vision-seeking trek in the Kampankis hills, July 2016

There are various motives behind the formation of integral territories for different peoples, including internal political factors and the need to resolve border disputes (Surrallés 2016). Wampis leaders stress the need for 'territorial defence' against external threats, and in particular, the urge to protect the Kampankis range of hills, which constitutes the core of the Wampis territory. It is here that many of the present generation's (grand-)parents settled along the headwaters before moving to the riverbanks in the 1960s and where they still hunt and fish. Crucially, it is also the place for vision-seeking (see below).

However, the Kampankis had not previously been titled, remaining nominally "state-owned" land. Wampis leaders had first sought to close this gap through categorising it as a conservation area, leading to a provisory status as 'reserved for national park' - the Zona Reservada Santiago Comaina. However, in 2004 an agreement to implement another new national park on the border with Ecuador, in 
untitled ancestral territory of the Awajún and Wampis (the Parque Nacional Ichigkat Muja - Cordillera del Cóndor) was revoked by the state under President Alan García: in a unilateral decision, the area of the park was cut almost by half, freeing up the remainder for mining concessions. To make matters worse, in 2007 an oil concession of over 853,000 hectares was issued (Lote 116), superposed on titled community lands and the Kampankis hill range (Barclay, García Hierro, and Huaco Palomino 2009; Garra 2012). Having lost trust in the state's willingness to conserve the area, Wampis leaders decided to advance the formation of the integral territory instead, which includes Kampankis.

The need to resist the imminent threat posed by the Lote 116 oil concession was the main motivation for Wampis to participate in large numbers in the two paro amazonico mobilisations in 2008 and 2009, alongside opposition to a package of legislative decrees that allowed the sale and individualisation of native title land (Manacés Valverde and Gómez Calleja 2010) and which culminated in the violent clashes at Bagua on 5 June. The resistance was successful inasmuch as the legislative decrees were derogated, and in August 2018 the Supreme Court cancelled the Lote 116 concession because it had not been consulted according to ILO convention 169, thereby setting a precedent for Peru. ${ }^{5}$

The neoliberal attack under President García not only called into question the legal basis of the Wampis' relationship with the state but also showed what its limitations were in the first place: what for the Wampis was their own territory, the state regarded as limited rights to the land surface. Repeatedly, I heard Wampis individuals mention how scandalised they were to hear from state agents that 'everything $30 \mathrm{~cm}$ below the ground belongs to the state'. This underscored their motivation to reclaim an 'integral territory', not only horizontally but also vertically, below and above the ground. In the section of the Wampis statute that opens this article, nonhumans cover the entire range of relationships to the

5 'Corte Superior suspende la exploración en el Lote 116 porque no fue consultada', La República, 29 August 2018 https://larepublica.pe/politica/1308055-corte-superior-suspendeexploracion-lote-116-consultada [accessed 19.09.2018]. 
territory, including forest, waterbodies (abode of tsunki, master of aquatic life), underground (abode of nunkui, mother of edible plants) but also the air and space.

The appearance of nonhumans in text written by Wampis themselves is a recent phenomenon. A review of the archive of FECOHRSA (Federación de Comunidades Huambisas del Río Santiago, one of the GTANW's precursors) for the period 1995-2009, which includes assembly minutes and correspondence with various authorities, shows an increasing prominence of conservationist terminology but hardly any mention of concepts in Wampis language and even fewer references to nonhuman agency. This can be explained by the aim of these documents, written in a formal style in a foreign language, to build legitimacy and gain recognition from the state, avoiding anything that may be judged as signs of 'irrationality and retrograde primitivism' (Alan García, cited above). The explicit importance assigned to ontological features in the Wampis statute of 2015 thus shows a recent change, which coincides with the Baguazo.

\section{Mobilising nonhumans for the defence of territory}

There are few explicit and public invocations of nonhumans registered for the period shortly before and during the Baguazo, but it can be argued that the ground was prepared there. Based on interviews with Awajún leaders about the internal dynamics of the mobilisation, Silvia Romio (2018) describes a revival of forms of organisation, leadership roles, the vision-seeking of warriors through ayahuasca rituals, the public exposition of such visions by elders and the performance of anen songs. The Wampis leaders I spoke with confirmed the important contribution of women who had stayed in the villages during the mobilisation, where they gathered to sing anen to protect their husbands and sons in faraway Bagua. The power of anen songs works through the invocation of nonhumans, ancestor spirits and the like. Many credit the fact that no Wampis were killed in the confrontation to the protective power of these songs, which were also communicated through non- 
traditional means such as radio transmitters. This 'public' quality of anen previously treated as secret knowledge - seems to be a new phenomenon. ${ }^{6}$

This ancestral knowledge was guarded, there were many women and men who knew - when there were internal conflicts, they used this practice too. Therefore, when this serious confrontation took place, the women and persons who knew these songs, the anen, had to do it, because this was effective. There was this belief, this faith. So, we said: Those who are of the religions, pray! Those who know anen, do it! Because therein is our power. We young people, ready with our laws, to dispute with them. (Juan Nuningo, interview, 23 April 2019). ${ }^{7}$

Juan Nuningo further mentioned that the volunteers preparing to travel to Bagua were asked to comment on their visions, and if a person had a dream that was interpreted as indicating weakness or danger he was recommended to stay at home. The qualities of the waimaku visionary warriors thereby gained new relevance, and in consequence so did vision-seeking practice and use of the psychoactive plants tobacco (tsaan), brugmansia (maikua) and ayahuasca (natem). After being out of fashion for a long time, due to missionary influence, the Wampis statute now contains a section about the 'duty to encourage [these plants] use in young people'. While these changes can be linked pretty directly to the Baguazo, for other practices that relate to nonhuman agency the connection is not so obvious.

Both Juan Nuningo and Julio Hinojosa explain that they came to realise the necessity of setting down the importance of nonhumans in writing due to the need to legally substantiate the ownership claim over the Kampankis hills. This happened

\footnotetext{
${ }^{6}$ In ethnographic literature, anen are described as secret knowledge, passed on like precious property and mostly sung in solitude or silently (Brown 1986; Codjia 2017).

7 'estaban guardados los conocimientos ancestrales, había muchas mujeres y varones que conocían - cuando al momento de estos problemas, conflictos internos, entre ellos también, hacían esta práctica. Entonces, cuando habido este enfrentamiento serio, esas mujeres conocen eso, personas que conocen los cantos anteriores, el anen, tenía que hacerlo, porque eso daba efecto. Había esa creencia, esa fe. Entonces decimos hay que hacer eso. Los que son de religiones, que ore! Los que conocen anen, también que lo hagan! Porque ahí esta nuestro poder. Eso ha sido así. Nosotros nuevos jóvenes, personas preparados con nuestros leyes, para discutir con ellos.'
} 
in the context of meetings and discussions about a cultural-historical mapping project in 2007 and 2008, shortly before the Baguazo.

Only then, in the assemblies, did we think: what is it that are we trying to protect? What is here? Here are the waterfalls and in the waterfalls there are the arutam [ancestor spirits]. In the mountains are the tijaes [forest people], right? And what dwells in the depths of the rivers and lakes? The tsunkis. And inside the earth? There is nunkui, who is sacred, she has to be respected. (Julio Hinojosa, interview 24 April 2019) ${ }^{8}$

This constituted a shift as, in Nuningo's words, before 'we only said that we defend our territory, our forest, because there are the medicinal plants, the animals that we eat, it's our market - only this'. Interestingly, Nuningo reckons that this was encouraged by the negotiations with state functionaries, who used the lack of sustento tecnico (technical justification) as an argument to put down Wampis demands. Understanding that the spiritual relationships with the territory were protected under ILO 169 and UNDRIP, Wampis leaders therefore sought to explain these connections in written form. The anxiety to stop the negative impacts of oil exploration made it especially urgent to insist that these relationships covered the underground realm as well: if tsunki, the "mother of the river", was scared away by noise and contamination, there would be no more fish; and regarding nunkui, 'for the oil exploration, they make the earth tremble, thus, they [nunkui] flee [...] the yucca loses productivity, the fertile soil can become infertile, it can't produce' (Julio Hinojosa). ${ }^{9}$ Note that these are impacts that Wampis believe already happen at the exploration stage, due to the use of explosives, noisy machines, motor-boats and so forth, which are otherwise seen as relatively unproblematic from an

\footnotetext{
8 'A hí recién, en las asambleas, hemos dado cuenta, porque vamos proteger? Que cosa hay acá? Acá están las cataratas, en las cataratas están los arutam. En las cordilleras están los tijaes. No? Y acá en algunas partes, están cuencas grandes como Santiago y Morona, y que cosa hay dentro en la profundidad? En los pozos. Están los tsunkis. Y interior de la tierra, que cosa esta? Esta nunkui, adentro, que es sagrada, hay que respectarla.'

9 'Nunkui - la exploración de petróleo, lo hacen temblar la tierra, entonces, ya pues, también se huyen [...] ya no da la productividad de la yuca, ya la tierra fértil puede volver a ser infértil, no puede producir.'
} 
environmentalist perspective. This perception of an existential threat, invisible to outsiders, helps to explain the Wampis' immediate and resolute resistance against the Lote 116 oil project. Furthermore, it contributed to the strategy devised to defend Wampis self-determination through the claims for the integral territory and formation of an autonomous government.

The first ordinance of the GTANW stresses the importance of nunkui, 'provider of fertility of the earth and the reproduction of seeds, guarantor of abundance and food security, facilitator of spiritual strength of women and inspiration for the norms and techniques for sustainable treatment of soils', and of tsunki, origin of 'the knowledge about management of the springs, aquatic fauna and fishery practices'. ${ }^{10}$ These beings are thus linked directly with the GTANW's desire to exert resource governance rights, framed in conservationist language. Nunkui and tsunki feature prominently as "frontline" nonhuman actors in GTANW communications, thanks to their analogies with other, better-known "Mother Earth" figures (pachamama) and Hollywood adaptations (e.g., the humanoid amphibian in The Shape of Water); their "underground" nature predisposes them for fighting oil and mining companies. The aptness of other beings is less obvious, but the GTANW is promoting discussions about their role and possible contributions to territorial defence. This includes a re-evaluation of storytelling, as "the real history of our people”. At an oral history workshop organised by the GTANW, elders revealed stories of different animal-human beings who had fought against oppression, drawing comparisons to present times. For instance, the history of the defeat of the unkaru crab, which was made possible by strategically coordinated actions by different animals, was pointed out as a guide for how the GTANW should proceed in countering extractivist projects.

There are also sinister forms of nonhuman action that do not easily lend themselves to public communication but nevertheless may intervene and shape political mobilisation. Foremost, this concerns witchcraft attacks, which can have political motivations and be directed against individuals as well as against entire

\footnotetext{
${ }^{10}$ Ordenanza No. 1; GTANW 2015.
} 
communities or kinship groups. For instance, I witnessed the defence measures taken in my host community after a visiting sorcerer had allegedly released a pasuk, a spirit being that can take the shape of different animals and humans and randomly causes illness among people who cross its path (see also Garra 2017, 76; Brown 1984, 209). The contracted defence sorcerer identified the motive for the attack as jealousy against the politically powerful community from a competing one close-by. While witchcraft is a constant, there seem to be changes in the interpretation of its motives. Recently, the GTANW communicated that a pasuk had appeared in the context of inter-communal conflict created by the divide-andrule tactics of an oil company that seeks to develop the Lote 64 concession close to Rio Morona. In the communique, the term "witchcraft" is avoided and the pasuk is framed as a 'cultural syndrome characterised by the Health Ministry as a collective psychosis'. As for the Wampis the 'state of [a person, or people's] health reflects the social situation [in which] we live', this is denounced as a 'heavy sociocultural impact' caused by the oil company. ${ }^{11}$

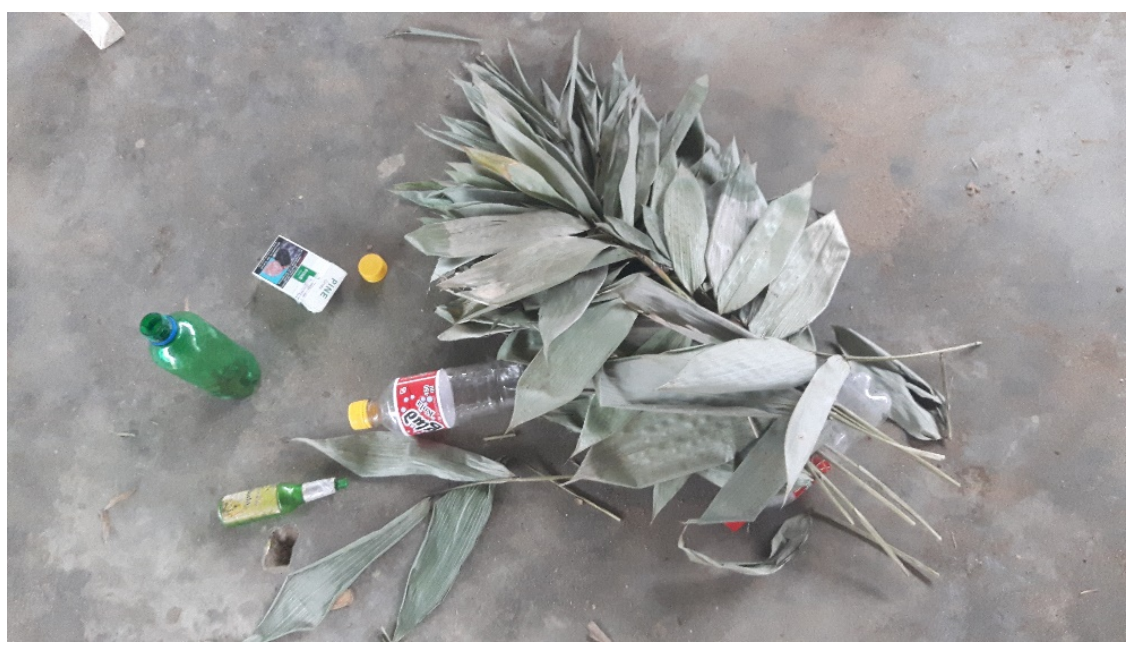

Working instruments left by the shaman after the expulsion of a pasuk spirit, February 2017

\footnotetext{
${ }^{11}$ 'GTANW denuncia grave impacto sociocultural de maniobras de Geopark Y Petroperu', 23 October 2018. www.nacionwampis.com/gtanw-denuncia-grave-impacto-sociocultural-demaniobras-de-geopark-y-petroperu-2 [accessed 15.11.2018]. See also Chirif and Barclay 2019.
} 
Another form of nonhuman, or rather quasi-human, action is the appearance pishtaco. Described as a tall, white, bearded gringo man, this vampire-like figure seeks victims in order to extract their fat and body parts. Alongside several reported sightings during my stay, in one case the origin of a pishtaco scare was my own visit to a remote community. Indeed, one of the tasks of my research partner, Geronimo Petsain, was to prevent such scares by carefully explaining the motives for my visits. There are several variations of the pishtaco figure (which has its origins in the Andes) but they all have (semi-)human form, sometimes disguised as government officials, vaccination crews or NGO workers to hide their intention of sucking out or extracting life energy or infecting people with deadly substances (Santos-Granero and Barclay 2011). Apparently, such sightings increased and took on a new quality around the time of the Bagua mobilisations, indicating that 'this time indigenous peoples are certain that the Peruvian State has allied with large extractive corporations not only to despoil native peoples from their life forces, but to exterminate them' (Santos-Granero and Barclay 2011). However, the existence of pishtaco is debated, or denied, by many Wampis and is even a source of ridicule among Wampis men with higher education. They do not appear in public communications of the GTANW. Still, the repeated appearance of pishtaco can be understood as indicating a deep suspicion about the motives of non-indigenous persons visiting Wampis territory and a reluctance to engage with them - a form of silent resistance.

\section{Vertical territoriality and the emergence of Wampis eco-autonomy}

The Wampis' struggle for autonomy has an intrinsic ecological dimension, ontologically rooted in manifold relationships with nonhuman actors. It seems likely that the latter did indeed contribute to the Baguazo uprising in 2009. Certainly, we can state their increased visibility for external audiences. Nunkui, tsunki and their cohorts have been around since time immemorial; their recent appearance in the context of eco-political mobilisations does not make them 'new' 
but reflects a strategic decision by the Wampis that it is time to let them speak to the rest of the world.

In 1995, Beth Conklin and Laura Graham described the tensions that emerge from the strategic alliance between indigenous movements and international environmentalism as Amazonian ethnic identity is represented as perfect embodiment of a "global ecological imaginary" and divergent interests are painted over: 'Environmentalists' primary goal is to promote sustainable systems of natural resource management. Indigenous peoples ultimately seek self-determination and control over their own resources' (Conklin and Graham 1995, 703). Since the late 1990s, the alliance has gained further traction through the strategic position indigenous peoples occupy in climate change negotiations. At the same time, indigenous peoples are increasingly trapped between the temptations of consumerism, external pressure to engage in extractivist enterprises (Rubenstein 2004) and Western imaginaries about the 'ecological native' (Ulloa 2005), in parallel to the continuation of the old "noble savage" trope. Indigenous groups that resist extractivist projects consistently face accusations of parroting a foreign discourse so as to capture NGO funds or of being naively instrumentalised to advance an eco-imperialist agenda against the development of the sovereign nationstate. In this context, what does the increased visibility of nonhumans mean for the GTANW's autonomy project and beyond? How does it change the positioning of indigenous peoples in eco-political struggles?

First, it needs to be pointed out that the increased visibility of nonhumans happens in line with changes in legal frameworks. As Alexandre Surrallés argues, the UNDRIP of 2007 has effectively extended human rights to nonhumans through provisions such as Article 25, which recognises the right of indigenous peoples to 'maintain and strengthen their distinctive spiritual relationship with their traditionally owned or otherwise occupied and used lands, territories, waters and coastal seas' - in animist cosmology, this can only refer to the entirety of affective exchanges with different nonhuman, animal, plant and spirit beings; therefore, the subject of fundamental law "moves from the "thinking subject" to the "feeling subject"' (Surrallés 2017). 
Wampis territoriality as expressed in relationships with nonhumans goes far beyond the fragmented "flat earth theory" commonly employed by state functionaries (limited rights to land surface). The vertical dimension of territoriality underground and space - makes for a holistic understanding of an integral territory, alive with interrelated beings that command respect in their own right. Not all of them are friendly but all form part of the Amazonian 'political economy of life', which is based on the belief that different beings, including humans, are in fierce competition for the scarce resource that is life energy (Santos-Granero and Barclay 2011). It calls attention to the fact that in many public declarations by Wampis and other indigenous peoples we find an emphasis on protecting "life", next to ecologist terminology of safeguarding "nature", the "environment", "ecosystems" and the like. Regarding the postulated tension between indigenous autonomy and conservationism, part of the solution thus appears hidden in plain sight: "life", "nature", "ecosystems" and similar terms seem to be used by Wampis leaders as placeholders for nonhumans, or rather, the entire web of life made from manifold relationships between humans and nonhumans and between different kinds of nonhumans. This creates an 'equivocation of translation' (Viveiros de Castro 2004): although using the same terminology, they may not mean the same thing as a Western ecologist when talking about "protecting nature".

Similarly, I suspect that the particularly strong reaction Wampis express against the danger of environmental contamination is in part due to the translation of 'pollution' into the Wampis word tseas, which means 'poison' - associated with fish poisoning, poisonous darts and poisoned beverages used to secretly kill enemies. Contamination can therefore be understood as a wilful act of aggression that aims at killing the victim in a most unpleasant way, going much further than the negligent diffusion of toxic chemicals into the environment by referring to a broad range of violent disruptions of human and nonhuman life. Such 'equivocations of translation' may give rise to many misunderstandings but nevertheless facilitate connection between indigenous ontologies and a strategic positioning within global environmentalist discourses. In effect, the "new" visibility of nonhumans proves wrong the accusations that Wampis may have merely adopted Western ecologist discourse for the self-interested pursuit of financial benefits derived from autonomy rights; on the contrary, it calls for interpreting such ecological discourse as an 
ontologically rooted "indigenous environmentalism" that is able to bridge contradictions between ecology and autonomy, towards something we could term "eco-autonomy". This is an emergent phenomenon, and there is no guarantee that in future the Wampis will not decide that the risk of annoying nunkui, and so getting less abundant manioc harvests, or of tsunki holding back the fish is worth taking compared to the immediate benefits of cash, jobs and education opportunities. Relationships with nonhumans are, after all, negotiable. Also, not all types of nonhumans are helpful in mobilising support from global publics. It is thus necessary to analyse when, how and why certain types of nonhumans enter the debate, while others do not, and to respect the decision of indigenous peoples themselves about the proper time and place to invoke nonhumans in their strategic communications.

\section{References}

Barclay, Frederica, Pedro García Hierro, and Marco Huaco Palomino. 2009. Crónica de un engaño. Los intentos de enajenación del territorio fronterizo Awajún en la Cordillera del Cóndor a favor de la minería. Lima: IWGIA.

Blaser, Mario. 2013. 'Ontological Conflicts and the Stories of Peoples in Spite of Europe’. Current Anthropology 54 (5): 547-68.

Brown, Michael F. 1984. Una paz incierta: Comunidades Aguarunas frente al impacto de la carretera marginal. Lima: CAAAP.

___ 1986. Tsewas Gift - Magic and Meaning in an Amazonian Society. Tuscaloosa: University of Alabama Press.

Campion, Minerva. 2018. 'The Construction of the Amazonian Borderlands through the Longue Durée: An Indigenous Perspective'. Journal of Borderlands Studies 33 (1): 123-40.

Codjia, Paul. 2017. 'Comment Attirer Le Gibier囚? Pratique Du Jeûne et Récitation de Chants Magiques Dans Les Activités Cynégétiques Wampis (Jivaro)’. Journal de 
La Société Des Américanistes 103 (2): 81-109.

Chirif, Alberto, and Frederica Barclay. 2019. El Lote 64, un mundo de conflictos. Riesgo de afectaciones a los derechos indigenas Achuar y Wampis por las empresas GeoPark y Petroperú. Lima: Equidad.

Chirif, Alberto, Pedro García Hierro, and Richard Chase-Smith. 1991. El indigena

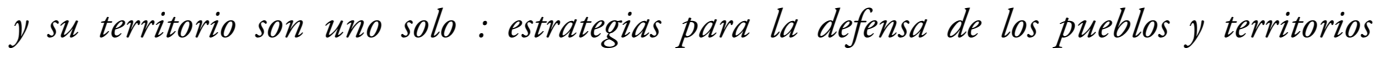
indigenas en la Cuenca Amazónica. Lima: Oxfam America, COICA.

Conklin, Beth A, and Laura R Graham. 1995. 'The Shifting Middle Ground: Amazonian Indians and Eco-Politics'. American Anthropologist 97 (4): 695-710.

De la Cadena, Marisol. 2015. Earth Beings: Ecologies of Practice across Andean Worlds. Durham, NC, and London: Duke University Press.

Espinosa, Oscar. 2009. '¿Salvajes opuestos al progreso?: Aproximaciones históricas y antropológicas a las movilizaciones indígenas en la Amazonía Peruana'. Anthropologica 27 (27): 123-68.

Garra, Simone. 2012. 'El despertar de Kumpanam: Historia y mito en el marco de un conflicto socioambiental en la Amazonía'. Anthropologica 30 (30): 5-28.

___ 2017. 'Les sorciers condamnés. Chamanisme et mutation dans le monde awajún (Amazonas, Pérou)'. PhD Thesis, Université Paris Nanterre.

Garra, Simone, and Raúl Riol Gala. 2014. 'Por el curso de las quebradas hacia el "territorio integral indígena": Autonomía, frontera y alianza entre los Awajún y Wampis'. Anthropologica 32 (32): 41-70.

Greene, Shane. 2009. Customizing Indigeneity: Paths to a Visionary Politics in Peru. Stanford, Calif: Stanford University Press.

Manacés Valverde, Jesús, and Carmen Gómez Calleja. 2010. 'Informe en minoría de la Comisión Especial para Investigar y Analizar los Sucesos de Bagua'. Lima.

Noningo, Shapiom. 2018. 'Gobierno Territorial Autónomo de la Nación Wampis: 
Recuperando la Autonomía sociohistórica, construcción del futuro común'. In Deforestación en Tiempos de Cambio Clmático, edited by Alberto Chirif, 83-92. Lima: IWGIA.

Romio, Silvia. 2018. 'El pre-Baguazo' y sus historias: Anatomía de un conflicto (Mayo-Junio 2009)'. Nuevo Mundo Mundos Nuevos (online ed.).

Rubenstein, Steven L. 2004. 'Steps to a Political Ecology of Amazonia'. Tipiti: Journal of the Society for the Anthropology of Lowland 2 (2): 131-76.

Santos-Granero, Fernando, and Frederica Barclay. 2011. 'Bundles, Stampers, and Flying Gringos: Native Perceptions of Capitalist Violence in Peruvian Amazonia'. Journal of Latin American and Caribbean Anthropology 16 (1): 143-67.

Surrallés, Alexandre. 2016. 'Derechos universales y posicionamientos locales: La Declaración de las Naciones Unidas para tres pueblos indígenas'. In Apus, Caciques y Presidentes. Lima: IWGIA.

—_ 2017. 'Human Rights for Non-Humans'. Hau: Journal of Ethnographic Theory 7 (3): 211-35.

Surrallés, Alexandre, and Ermeto Tuesta. 2017. 'Los Territorios Integrales y la libre determinación de los pueblos en la Amazonía noroeste del Perú'. In Atlas de Comunidades Nativas, 54-60. Lima: Instituto del Bien Comun.

Ulloa, Astrid. 2005. The Ecological Native: Indigenous Peoples' Movements and EcoGovernmentality in Columbia. New York: Routledge.

Viveiros de Castro, Eduardo. 2004. 'Perspectival Anthropology and the Method of Controlled Equivocation'. Tipiti: Journal of the Society for the Anthropology of Lowland South America 2 (1): 1. 